\title{
THE BATIH FAMILY AS A WEAPON: ANALYSIS OF THE JOLO CATHEDRAL BOMB, PHILIPPINES
}

\author{
Al Chaidar ${ }^{1}$, Herdi Sahrasad ${ }^{2}$, Dedy Tabrani ${ }^{3}$ \\ ${ }^{1}$ Senior Lecturer at University of Malikussaleh, Aceh and PhD candidate at \\ Department of Anthropology, University of Indonesia. \\ 2 Senior Lecturer at University of Paramadina, and Department of Politics, \\ University of Muhammadiyah Jakarta. \\ ${ }^{3}$ Candidate at PTIK, Police Science College Jakarta. \\ Korespondensi: alchaidar@unimal.ac.id
}

\begin{abstract}
This article explain about terrorist's bombing toward a Roman Catholic cathedral in Jolo, southern Philippines, Sunday 27 January 2019 morning. At least 22 people were reportedly killed tragically and nearly 50 others were injured. The suicide bombing of the husband and wife exploded during Sunday Mass in Jolo is the first bomb explosion was carried out by a woman from inside the church who smashed benches, smashed windows and left the body of the victim at the Catholic church located in Jolo. The first explosion occurred at Jolo Cathedral in Sulu Province. The second bomb exploded outside the church after the congregation left to save themselves. The second bomb was carried out by a man who was the husband of the first bomber. This Jolo suicide bombing mimics the suicide bombing of a family of 8-9 May 2018 in Surabaya and Sidoarjo. Nobody thought that the perpetrators came from one whole family. Officers revealed that the bombers in the three churches were the families of Mr. Dita Oepriyanto and Mrs. Puji Kuswati. These parents invited their four children to take action in three different churches. Their four children have a very young and young age. Yusuf Fadil's son (18), Firman Halim (16), daughter of Fadhila Sari (12), and Pamela Riskita (9). The familial terroist bombing in Jolo dan Surabaya is a reflection that our world today is 'a world full of the thrill of underground revenge, inexhaustible and never satisfied in an explosion'. The present is a age of anger
\end{abstract}

Keywords: anger, age, Muslim, terrorist, Jolo, Surabaya, familial terrorism, ISIS 
Aceh Anthropological Journal, Vol. 3, No. 2, hlm: 114-128, Oktober 2019

\section{A. Introduction}

Two explosions occurred outside a Roman Catholic cathedral on the southern Philippines island, Sunday, January 27, 2019 morning. At least 22 people were reported killed and nearly 50 others injured. The explosion incident from the bomb exploded during Sunday Mass. The first bomb explosion was carried out by a woman from inside the church who smashed benches, smashed windows and left the body of the victim at the Catholic church located in Jolo.

The first explosion occurred at Jolo Cathedral in Sulu Province. The second bomb exploded outside the church after the congregation left to save themselves. The second bomb was carried out by a man who was the husband of the first bomber. A number of victims were lying on the road outside Our Lady of Mount Carmel Cathedral, which had also been rocked by a previous bomb explosion that was placed in a utility box on a motorcycle in a parking area outside the church.

Suicide bombing is a new phenomenon for the Philippines. Typically, terrorists in the Philippines respect their bodies, families and worshipers highly from the deadly bomb blast. The rebels in the southern Philippines have never carried out suicide bombings (isytishad). Today, with the presence of an anonymous paramilitary (anonymous soldier) from Indonesia, the stage of terror is becoming increasingly dire in Southeast Asia. Multicultural civil society and pacifists of different religions have always been the target of terror from radical groups who have never lived in a warm and intolerant tolerance.

Our world today is 'a world full of the thrill of underground revenge, inexhaustible and never satisfied in an explosion'. The present is a century of anger (Pankaj Mishra, The Age of Anger, 2017: 13). There is widespread panic, originating from the despotic forces of both East and West in the face of this age of anger.

\section{B. Notes On Methodology}

This study uses qualitative methodologies with involves a phenomenological perspective, participant observation and personal reflections whereby our aim to understand, report, and evaluated the meaning of events for the bombing of a Roman Catholic cathedral in Jolo, southern Philippines, Sunday 27 January 2019 
morning. The suicide bombing of the husband and wife exploded during Sunday Mass in Jolo. At least 22 people were reportedly killed tragically and nearly 50 others were injured. The focus of these qualitative methodologies is the ways in which participants (rather than the researcher) interpret their experiences and construct reality. The steps in this qualitative study implies an emphasis on process and indepth understanding of perceived meaning, interpretation, and behaviors, in contrast with the measurement of the quantity, frequency, or intensity of some externally defined variables. We will also use participant observation method which the writers are immersed in the action being observed but my role as researcher is not obvious and unstructured interviews.

As researchers who is using participant observation, we must be aware of the ethical implications of this methodology. In this, we are as researchers still participates in, as well as observer, the action which requires me as the researchers to reflect upon, and evaluate, my own experiences, memories, values, and opinions in relations to a specific issue or topic.

\section{Discussion: A Husband and Wife from Indonesia as Actors}

According to the SITE Intelligence Group, ISIS (Islamic State of Iraq and Syria) through an official announcement claimed the attack was carried out by two suicide bombers, a husband and wife from Indonesia. Two Indonesian suicide bombers were behind the Catholic church attack on Jolo Island, Sulu Province. The husband and wife responsible (in this attack) are Indonesian suicide bombers who might get a doctrine in Surabaya. The Abu Sayyaf group only directed them, starting from learning targets, carrying out secret monitoring and bringing the couple to church. During the bombing, the wife sat in the church while her husband came out. The woman, who was depicted wearing a gray-colored jacket, carrying a backpack carried out the first suicide bombing. The husband then detonated a second suicide bomb outside the church.

Previously, this church was also bombed which occurred a few days after the referendum on the expansion of regional autonomy, the Bangsamoro Autonomous Region in the Muslim Mindanao region which also included Jolo Island, Sulu Province. Jolo has been known as one of the bases of the Abu Sayyaf terrorist group 
which since 2013 has been affiliated with the Islamic State of Iraq and Syria (NIIS). The presence of the bombing couple from Indonesia is of course to provide doctrinal confirmation of attacks in the name of religion. There is the role of organic violence scholars who have structured the mindset of this family's suicide bombers. This husband and wife are only weapons used by violent intellectuals in the conception of Bruce Hoffman (2004).

The suicide bombing of a married couple from Indonesia is likely to be related doctrinally or organizationally with the terror attack of a family suicide bomb in Surabaya 8-9 May 2018. There are doctrines of fatalism and anti-structural strategies that make it difficult for all governments to overcome this type of terror. The public and the research world are also very surprised and hope that the suicide bombers of this family can explain more before they do the action. If the SM Kartosoewirjo guerrilla family story we can hear many very open, brave and syariah explanations that the Darul Islam / Islamic State of Indonesia (DI / NII) wants an Islamic-based system and system of society, then in the family terrorists today, it is difficult to find an explanation other than the statement of the existence of their own sect.

In this age of anger, terrorists are invading and hitting anyone indiscriminately, even civilians of their religion. All the attacks of anger over the global injustice and modern oppression and unjust tyranny-against Muslims in Palestine, Bosnia, Rohingya, Aceh, Mindanao, Pattani, Poso, Ambon, Orlando, Xinjiang Uighurs, Cairo, Brussels, Spain, Baghdad and others else - there was never an adequate explanation of why it all happened.

Supposedly, with the mission of isytishad (suicide bombing) they no longer need to be afraid to voice their aspirations. The lives have been lost, there is no need to be afraid anymore of the cruel interrogation of any secret service.

Human lives need not have to be sacrificed for a sect or movement, but rather lives should be offered for the sake of the religion of God Almighty alone. The triumph of religion will impact on the triumph of human civilization, on movements that respect other human rights of life of different religions, schools, sects and ideologies. 
Aceh Anthropological Journal, Vol. 3, No. 2, hlm: 114-128, Oktober 2019

\section{Family Suicide Bombing}

The Jolo bomb is a nuclear family suicide bomb. The Batih family is the smallest social organization of humankind that has ideological, political, social, cultural, economic and security and security forces. The suicide bombing as a family has a devastating effect. The world is shocked by the sacrifice of the lives of those who struggle pragmatically to achieve the paradise promised by God. However, a suicide bombing as a family left a mark of significant lessons and explanations so that the world community understood why all this happened. The superiority of Homo sapiens is that it is a unique language that provides explanations for various missions in this mysterious life (Harari, 2017: 21).

This suicide bombing mimics the suicide bombing of a family of 8-9 May 2018 in Surabaya and Sidoarjo. Nobody thought that the perpetrators came from one whole family. Officers revealed that the bombers in the three churches were the families of Mr. Dita Oepriyanto and Mrs. Puji Kuswati. These parents invited their four children to take action in three different churches. Their four children have a very young and young age. Yusuf Fadil's son (18), Firman Halim (16), daughter of Fadhila Sari (12), and Pamela Riskita (9). This family lives in an elite residential area located in Wonorejo, Surabaya. I predict, if there is no significant counter discourse, then this family suicide terror will continue to flourish and become a trend in contestation between radical terror groups.

We should note that before the husband and wife bomb at Jolo Cathedral, Philippines, a family bomb attack had occurred in Surabaya where the world was shocked by suicide bombings carried out by one family in Surabaya and Sidoarjo 89 May 2018. The explosion occurred at the Catholic Church of Santa Maria Blameless on Jalan Ngagel Utara North, Indonesian Christian Church on Jalan Diponegoro 146 and Pentecostal Church in Surabaya (GPPS) on Jalan Arjuna.

The world is struck by a strange phenomenon which cannot be explained by any theory about the radical attitude taken by a family, together committing suicide in a place perceived as a pagan place. 
The selection of church targets shows how Wahhabi ideology does not value human values. The bomb blast at the Indonesian Christian Church (GKI) Jalan Diponegoro Surabaya, East Java, is estimated to occur around 07.45 WIB. The alleged perpetrator is a mother who carries two children under the age of five (toddlers). All three died instantly at the scene.

All terrorist attacks usually do not involve children under five as warriors of sectarian warfare terrorism. It was unthinkable how at first a mother by cooperating with two children under the age of five forced her to enter the convention room at GKI Jalan Diponegoro Surabaya at around 7.45 WIB.

At that time the service at GKI Jalan Diponegoro Surabaya had not yet begun. According to the schedule, the service will take place at $08.00 \mathrm{WIB}$. The mother and her two children who tried to enter the convention room were driven away by a security officer at the entrance of GKI Jalan Diponegoro Surabaya, before the three of them then blew themselves up in the churchyard.

While the explosion that occurred at Surabaya Central Pentecostal Church (GPPS) on Arjuno Highway, allegedly came from a car bomb. A car bomb occurred in the churchyard by crashing on the door. The three locations of the blast, according to police data, occurred right in front of the Church of Blameless Santa Maria on Jalan Ngagel Madya, GKI Diponegoro on Jalan Raya Diponegoro, and the Pentecostal Church on Jalan Arjuno.

They and their families want to go to heaven together, an eschatological ideal that is extraordinary. Terrorism is indeed a choice of 'millenarian' strategy in combating secularism, liberalism and capitalism, and socialism. Millenarians truly believe in life after death which is better for anyone who strives for His religion. It's just that they perceive the wrong fighting method.

Not to mention after the grief caused by the bomb terror in three churches in Surabaya, an explosion was reported back in Sidoarjo, East Java, Sunday night May 13, 2018 which was also carried out by a family terrorism. The explosion occurred in a rusunawa in Wonocolo Village, Taman District. Precisely on the 5th floor room No. B2. 
The residential building is behind the Taman Sidoarjo Police Station. This family terrorism attack has very little effect; even unable to undermine the capitalism, secularism and democracy that they have hated.

Seeing the bombings carried out by the family, then Anthropologically we must see what moved this family to carry out suicide bombings while attacking people of different faiths with them.

In anthropological bibliography, family terrorism is a new thing. Although there have been situations of disappointment and mental illness in the aftermath of war in post-Nazi Germany in 1944 and in Aceh after the Aceh-Dutch War of 1879, the two spectrums differ in terms of suicide after the war.

What happened in Surabaya and Sidoarjo today was an attack, a small battle that was played by very happy families, owned quite a decent amount of property, but made a conscious suicide bombing.

It is inconceivable how this family sacrificed their own cute and adorable children in an attack on their own neighbors who had not been hostile or attacked them.

There are no 'infidels' (non-Muslim infested) in Surabaya and Sidoarjo. There are no settings for civil war situations such as in Syria and Iraq or in Ambon, Ternate (2000) or in Poso.

What kind of explanation can science provide for this very surprising phenomenon?

In the perspective of Robertus Robert (2016), suicide bombings have added value, namely that by sacrificing themselves in actions carried out themselves, they will place opponents in moral shame. The idea behind suicide bombing has religious, heavenly and millenarian values. This idea was instilled doctrinally by organic violence scholars as intellectual actors. The social structure of suicide bombings places the perpetrators as victims who can only fight repression with their own bones and flesh and always sacrifice pacifist civilians or unarmed officers and always save intellectual violence. 
Thus, as explained by Mia Bloom (2005) and Ami Pedahzur (2006), in every suicide bombing, there is always a moral reversal, where the perpetrators in extreme acts of suicide change from criminals to martyrs - at least for themselves, groups of worshipers and sympathizers.

Bloom (2005) finally stressed that terrorist suicide is a form of political theater, where the audience's reaction is as important as the act of suicide itself. In further researching the motives for suicide bombing, Bloom found practical arguments, namely individual motives, organizational motives, and motives for competition between terrorist organizations. Bloom, like many other theorists, sees terrorism as a realization of actions with negative political motives, namely extreme violence. Political motives are regarded as the only thing that encourages or shapes action. (Bloom, 2005; Pedahzur, 2006). This motif does not appear purely as an awareness of the perpetrators and their partners, or even their children, but is injected by the violent organic intellectuals who always nurture them through preaching and indoctrination.

So far, three acts of terrorism carried out by three families while involving women and children in a series of terror in Surabaya (2018) are new phenomena, dramatic and set a new precedent, because this is the first time in the world. Previously, ISIS had lost much territory in Iraq and Syria. The group led by Abubakar Al Baghdadi is now suppressed at the borders of the two countries and spread across various countries. ISIS then pursued a coalition strategy with local groups and opened territorial bases such as in Marawi, Southern Philippines, along with Maute and Abu Sayyaf groups. However, after fighting for about five months, NIIS bases were destroyed. Many people condemned this "heinous act" without the slightest sense of humanity. Terrorism is cruel violence because it kills innocent pacifists who have never been involved in the cosmic war of terrorists against superpowers. 
Aceh Anthropological Journal, Vol. 3, No. 2, hlm: 114-128, Oktober 2019

\section{Family Terrorism in Jolo, Philippines}

The explosion of two suicide bombs in Jol Church, Sulu Province, Southern Philippines on January 27, 2019 has shaken the atmosphere of security in the Muslim-majority region. The double suicide bomber is a husband and wife from Indonesia who have long joined together with the Abu Sayyaf group.

The Abu Sayyaf group is a jihad corporation designated by ISIS (Islamic State of Iraq and Syam) as the territorial command of Southeast Asia. ISIS fanatics in Indonesia also flocked to pilgrimage to Mindanao, the operational area of the Abu Sayyaf terrorist group. They are anonymous soldiers who are not paid (anonymous soldier). They are the people who reject the peace agreement and cooperation in any form with the opposing party who is perceived as a thogut (enemy).

Last week, a referendum attended by 2.8 million people agreed on the establishment of the Bangsamoro Autonomous Region in the southern Philippines, the largest Muslim population in the country. The majority of voters agreed to the formation, but voters in Sulu Province which included Jolo were different. Residents of the area reject the special autonomy. The aim of the Indonesian couple is to set an example and influence Filipino terrorists to carry out suicide bombings. President Duterte said the husband and wife suicide bomber was behind the church bombing and he condemned this attack and ordered the military to destroy the Abu Sayyaf in any way.

\section{Failed to Enter Syria}

The Republic of Indonesia police (Regarding Indonesia \& Sindonews, 2019/07/24) have confirmed the bombing of the church in Jolo, the Philippines in January, was a suicide attack by a married couple from Indonesia. The couple tried to enter ISIS, Syria, but failed because they were deported by Turkey. Rullie and Ulfah were allegedly trapped with their three children in Turkey for almost a year before they were arrested and deported. They attended a short rehabilitation program upon returning to Indonesia and were allowed to go home. 
They have never set foot in Syria because they are deportees, arrested in Turkey before they can cross into Syria and the whereabouts of their children is also unknown. (Sydney Jones, 2019).

Rullie couple Rian Zeke and Ulfah Handayani Saleh went to Turkey in 2016 hoping to cross the border into Syria. Instead, they were arrested in January 2017 and sent back to Indonesia.

The bombing, which consisted of two explosions, struck the Cathedral of Our Lady of Mount Carmel in southern Jolo, Philippines, where the local military is fighting Muslim insurgents. The suicide bomb attack killed 23 people and injured more than 100 others. The attack happened right when the church gathered for mass. Through various online bulletins, Islamic State or ISIS groups claim responsibility.

Officials and independent experts have warned that Indonesia and other Southeast Asian countries face serious threats from hundreds of refugees who travel to Syria and Iraq to join ISIS. This attack shows that Southeast Asian countries must also be on the lookout for those who are deported from other countries before they can achieve their goals.

"This is the first suicide bombing that we know of was carried out by deportees," said Sidney Jones, director of the Jakarta-based Conflict Policy Analysis Institute. Several others have been involved in terrorist activities, but none on this scale.

Jolo has become a hotbed of Muslim rebel insurgency and home to the violent separatist militias, Abu Sayyaf, who support ISIS ideology. Philippine authorities initially blamed the Abu Sayyaf for the bombing of the church, and the attackers allegedly got help from the group.

Rullie and Ulfah were identified during interrogation of two suspects who were arrested in Malaysia in May. The role of the Indonesian couple in the bombing of the church in the Philippines shows the regional nature of militants affiliated with ISIS and who operate across borders as they pursue their goals, namely creating the caliphate of Southeast Asia which will include Indonesia, Malaysia and the Philippines. 
This shows the need for every police force in the region to understand extremist networks in neighboring countries, "Jones, known as a leading expert on terrorism in Southeast Asia, was quoted as saying by the New York Times.

A year ago, a married couple led their four children on a suicide mission in Surabaya, the second largest city in Indonesia. They carried out suicide bombings in three churches on Sunday morning that killed the family and 12 others. ISIS claims to claim responsibility for the attack.

In 2017, authorities identified seven Indonesian youths who joined ISIS, but went to the southern Philippines, not to Syria or Iraq. They joined the battle against the Philippine government in the city of Marawi, which was finally destroyed by fighting.

Sydney Jones said the bombing of the Jolo cathedral would add to the debate about how each country must deal with its citizens who were captured in ISIS territory and held in camps in Syria.

Some Indonesians and Malaysians have expressed a desire to go home, but there is no great enthusiasm to bring them back and until now, there has not been a clear program to do so.

\section{New Doctrine}

The Philippines has experienced a long history of Muslim rebellion in Mindanao. This Muslim rebellion has experienced a turning point as a history of terror since 1993. However, of all the series of terror attacks in the southern region, there has never been a single suicide attack that involved a husband and wife from a whole family of batih. This Jolo bomb attack proves the existence of new doctrines imported from Indonesia.

In Indonesia, familial suicide terrorism first appeared on 8 and 9 May 2018 in Surabaya, which struck churches and police stations. The world is stunned by this action that is difficult to accept common sense. Researchers find it difficult to find a theoretical basis to provide adequate explanation for the existence of terror attacks that actually sacrificed the families of the perpetrators of the perpetrators after killing church civilians who are considered enemies. 
The takfiri doctrine that has been adopted by Wahhabi religious figures in the Middle East is considered as a destructive doctrine. This doctrine has humiliated the peaceful religion of Islam and blessed all the world. There is a new development of this doctrine which is considered to be local and initiated by fatalist violent scholars.

Violent scholars are religious intellectuals who are organic in nature. These organic intellectuals, according to Antonio Gramsci (1971) are intellectuals who emerged from exclusive schools who adopted radical schools of thought and then applied them organically in their liminal and closed communities. It is this organic cleric who then radicalizes the worshipers who are loyal followers who are fanatical. Congregations who were indoctrinated for a long time by using all the propositions and references of books from certain schools that are very selective. This organic cleric then tried to answer many questions faced by his congregation quickly, accurately and thoroughly.

When facing problems that are difficult to solve at the community level, the issues of resistance strategies are finally brought into the realm of violence to solve them. At this stage, organic clerics become violent clerics which Bruce Hoffman conceptualized as violent intellectuals, which in my theoretical terminology is violent clerics or violent organic clerics. The meaning of violence here is not only as radical, but also as a terrorist who removes the element of humanity in each of these deadly fatwas.

The loss of humanity is the most visible indication where these violent scholars began to speak in a high-pitched, angry, full of mistrust and full of threats and curses. With the loss of humanity, the violent organic cleric then offered the most fatal resistance solution: the suicide bombing of a family.

A number of propositions are then interpreted in a bloody semiotics that are claimed to be in accordance with God's will. The suicide bombers were asked not to fight on their own, but also to invite his wife to not be left behind who is feared to be seduced by thoguts (enemies of the devil). Not only is it enough there, this violent organic cleric then even ordered that the children of the husband and wife be taken 
Aceh Anthropological Journal, Vol. 3, No. 2, hlm: 114-128, Oktober 2019

along and pick up the paradise that had been promised according to their eschatological beliefs.

\section{Closing}

The aim of the Indonesian couple is to set an example and influence Filipino terrorists to carry out suicide bombings. From history we learn from the past that Indonesians have always been the originators of the beginning (Agung Pribadi, 2013) of many events.

The Indonesians involved in the Bangsamoro struggle in Mindanao, Southern Philippines, instead provided a deadly solution that was difficult to accept common sense. This fatalist idea was not only put forward as a suggestion, but also offered him to be a martyr in the attack.

Zamboanga, Davao, Cagayan de Oro are ideal terrorist targets. Last week, a referendum attended by 2.8 million people agreed on the formation of the Bangsamoro Organic Law (BOL) in the southern Philippines, the largest Muslim population in the country which also includes the Sulu Province.

The majority of voters agreed to the formation, but voters in Sulu Province which included Jolo were different. Residents of the Jolo region, the Sulu archipelago, reject the special autonomy. President Duterte said the husband and wife suicide bomber was behind the church bombing and he condemned this attack and ordered the military to destroy the Abu Sayyaf in any way. The presence of an anonymous soldier from Indonesia in Mindanao will create a new mess that is difficult to resolve. 


\section{References}

Agara, Tunde. 2015. “Gendering Terrorism: Women, Gender, Terrorism and Suicide Bombers," International Journal of Humanities and Social Science, Vol. Vol. 5, No. 6.

Alakoc, Burcu Pinar. 2017 "When Suicide Kills: An Empirical Analysis of the Lethality of Suicide Terrorism," International Journal of Conflict and Violence, Vol. 11, No. 8.

Baudrillard, Jean. 1999. Simulacra and Simulation. Translated by Sheila Faria, University of Michigan Press.

Bloom Mia and Chelsea Dyamond. 2018. Assessing the Future Threat: ISIS's Virtual Caliphate-Orbis- June 25.

Bloom, Mia. 2005. Dying to Kill: The Allure of Suicide Terrorism. New York: Columbia University Press.

Brym, Robert J. and Bader Araj. 2006 "Suicide Bombing as Strategy and Interaction: The Case of the Second Intifada," Social Forces, Vol. 84, No. 4.

Bultmann, Rudolf. 1975. History and Eschatology: The Presence of Eternity (1954-55 Gifford lectures). Greenwood Publishers.

Chaidar, Al. 2018. "Catatan Kritis atas UU Antiterorisme”, Kompas 4 Juni.

Fraser, Andrew. 2017 "Martyrdom's Children: The Tragedy of Child Suicide Bombers in Afghanistan," Canadian Military Journal , Vol. 17, No. 3.

Gramsci, Antonio, and Quitin Hoare. 1971. Selections from the prison notebooks. Vol. 294. London: Lawrence and Wishart.

Gray, David H. and Tom Owen Matchin. 2008. "Children: The new face of terrorism," International NGO Journal, Vol. 3, No. 6.

Hoffman, Bruce. 2006. Inside terrorism. Washington: Columbia University Press.

Hwang, Julie Chernov. and Kirsten E. Schulze. 2018. "Why They Join: Pathways into Indonesian Jihadist Organizations", Terrorism and Political Violence.

Ismail, Noor Huda. 2018. Ideologi Kematian Keluarga Teroris, artikel, CNN Indonesia https://www.cnnindonesia.com/nasional/20180515113011-21298324/ideologi-kematian-keluarga-terorisaccessed Selasa, 15/05/2018 12:30 WIB.

Jacques, Karen. and Paul J. Taylor. 2013. "Myths and Realities of Female-Perpetrated Terrorism". Law and Human Behavior, Vol. 31, No. 1. 
Aceh Anthropological Journal, Vol. 3, No. 2, hlm: 114-128, Oktober 2019

Kolakowski, Leszek, Main Current of Marxism, Vol. III, Clarendom Press, Oxford, 1978.

Nuraniyah, Nava. 2018. "Not just Brainwashed: Understanding the Radicalization of Indonesian Female Supporters of the Islamic State," Terrorism and Political Violence.

Pedahzur, Ami. 2005. Suicide Terrorism, Cambridge: Polity.

Robert, Robertus. 2016. "Struktur Bunuh Diri Teroris", opinion, Kompas daily, 26 January.

Sahrasad, Herdi dan Al Chaidar. 2018 'Tamkin' terrorism a new security threat, The Jakarta Post, Saturday, Nov 17.

Schuurman, Bart. Edwin Bakker, Paul Gill and Noemie Bouhana. 2018. "Lone Actor Terrorist Attack Planning and Preparation: A Data-Driven Analysis,” Journal of Forensic Science, Volume 4, No. 4.

Wickham, Carrie. 2003. Islamic Activism: A Social Movement Theory Approach, Indiana University Press.

Wiktorowicz, Quintan. 2001. "A Genealogy of Radical Islam.” Middle East Policy, Vol. VIII, NO. 4. 